\title{
Age-related changes of some trace element contents in intact thyroid of males investigated by energy dispersive $\mathbf{x}$-ray fluorescent analysis
}

\begin{abstract}
A prevalence of thyroid dysfunction is higher in the elderly as compared to the younger population. An excess or deficiency of trace element contents in thyroid play important role in goitro- and carcinogenesis of gland. The variation with age of the mass fraction of six trace elements $(\mathrm{Br}, \mathrm{Cu}, \mathrm{Fe}, \mathrm{Rb}, \mathrm{Sr}$, and $\mathrm{Zn}$ ) in intact (normal) thyroid of 71 males (mean age 37.3 years, range $2.0-80$ ) was investigated by ${ }^{109} \mathrm{Cd}$ radionuclide-induced energy dispersive $\mathrm{X}$-ray fluorescent analysis. Mean values \pm standard error of mean for mass fractions (mg/ $\mathrm{kg}$, on dry-mass basis) of the trace elements studied were: $\mathrm{Br} 10.8 \pm 1.3, \mathrm{Cu} 4.25 \pm 0.20, \mathrm{Fe}$ $221 \pm 13$, Rb $10.1 \pm 0.89, \mathrm{Sr} 4.52 \pm 0.43$, and $\mathrm{Zn} 122 \pm 5$. This work revealed that there is a significant tendency for an increase in $\mathrm{Zn}$ mass fraction in normal male thyroid from age 36 years to the eight decade. Moreover, a great disturbance of intrathyroidal trace element relationships with increasing age was found. Therefore, a goitrogenic and carcinogenic effect of excessive $\mathrm{Zn}$ level in the thyroid of old males and of disturbance in intrathyroidal trace element relationships with increasing age may be assumed
\end{abstract}

Keywords: thyroid, trace elements, age-related changes, energy dispersive x-ray, fluorescent analysis
Volume I Issue 5 - 2017

\author{
Vladimir Zaichick,' Sofia Zaichick² \\ 'Department of Radionuclide Diagnostics, Medical Radiological \\ Research Centre, Russia \\ 2Laboratory of Feinberg School of Medicine, Northwestern \\ University, USA
}

\section{Correspondence: Vladimir Zaichick, Department of Radionuclide Diagnostics, Medical Radiological Research Centre, Russia, Tel +7 (48439) 60289, Fax+7 (495) 956 I440,} Email vezai@obninsk.com

Received: April 19, 2017 | Published: July 21, 2017
Abbreviations: 109Cd EDXRF, 109cd radionuclide-induced energy-dispersive $\mathrm{x}$-ray fluorescence analysis; CRM/SRM, certified/ standard reference materials; IAEA, international atomic energy agency

\section{Introduction}

The endocrine organs, including the thyroid gland, undergo important functional changes during aging and a prevalence of thyroid dysfunction is higher in the elderly as compared to the younger population. ${ }^{1,2}$ Advancing age is known to influence the formation of adenomatous goiter and thyroid cancer. ${ }^{3}$ The prevalence of thyroid nodules is increased in the elderly, reaching a frequency of nearly $50 \%$ by the age of $65 .{ }^{4}$ Both prevalence and aggressiveness of thyroid cancer increase with age. ${ }^{2}$ Women are affected by thyroid nodule and cancer two to five times more often than men, but in age over 65 years a prevalence of thyroid cancer is higher in men..$^{2-5}$

Aging is a complex process involving biochemical and morphologic changes in single cells, in organs, and in the whole organism. One of the most generally accepted explanations of how aging occurs at the molecular level is the oxidative stress hypothesis. ${ }^{6}$ Reactive oxygen species (ROS) are widely considered to be a causal factor not only in aging but in a number of pathological conditions, including carcinogenesis. Aging, considered as an impairment of body functions over time, caused by the accumulation of molecular damage in DNA, proteins and lipids, is also characterized by an increase in intracellular oxidative stress due to the progressive decrease of the intracellular ROS scavenging. ${ }^{7}$ Oxidative damage to cellular macromolecules which induce cancer can also arise through overproduction of ROS and faulty antioxidant and/or DNA repair mechanisms. ${ }^{8}$ Overproduction of ROS is associated with inflammation, radiation, and some other factors, including overload of some trace elements, in both blood and certain tissues, or deficiency of other trace elements with antioxidant properties. ${ }^{9-15}$ Studies have shown that the imbalance in the composition of trace elements may cause different types of pathology. The importance of appropriate levels of many trace elements is indisputable, due to their beneficial roles when in specific concentration ranges, while on the other hand they can cause toxic effects with excessively high or low concentrations. ${ }^{12}$

In our previous studies ${ }^{16-24}$ the high mass fraction of iodine and some other trace element were observed in intact human thyroid gland when compared with their levels in non-thyroid soft tissues of the human body. However, some questions about the age-dependence of trace element mass fraction in thyroid of adult and, particularly, elderly females still remain unanswered. One valuable way to elucidate the situation is to compare the mass fractions of trace elements in young adult (the control group) with those in older adult and geriatric thyroid. The findings of the excess or deficiency of trace element contents in thyroid and the perturbations of their relative proportions in glands of adult and elderly males, may give an indication of their role in a higher prevalence of thyroid cancer in the elderly males.

The reliable data on trace element mass fractions in normal geriatric thyroid is apparently extremely limited. There are many studies regarding trace element content in human thyroid, using chemical techniques and instrumental methods. ${ }^{25-30}$ However, the majority of these data are based on measurements of processed tissue and in many studies tissue samples are ashed before analysis. In other cases, thyroid samples are treated with solvents (distilled water, ethanol etc) and then are dried at a high temperature for many hours. There is evidence that certain quantities of trace elements are lost as a result of such treatment. ${ }^{31-33}$ Moreover, only a few of these studies employed quality control using certified/standard reference materials (CRM/SRM) for determination of the trace element mass fractions. 
This work had three aims. The primary purpose of this study was to determine reliable values for the bromine $(\mathrm{Br})$, coper $(\mathrm{Cu})$, iron $(\mathrm{Fe})$, rubidium $(\mathrm{Rb})$, strontium $(\mathrm{Sr})$, and zinc $(\mathrm{Zn})$ mass fractions in the normal (intact) thyroid of subjects ranging from children to elderly males using $109 \mathrm{Cd}$ radionuclide-induced energy-dispersive $\mathrm{X}$-ray fluorescence analysis (109Cd EDXRF). The second aim was to compare the $\mathrm{Br}, \mathrm{Cu}, \mathrm{Fe}, \mathrm{Rb}, \mathrm{Sr}$, and $\mathrm{Zn}$ mass fractions in thyroid gland of age group 2 (adults and elderly persons aged 36 to 80 years), with those of group 1 (from 2.0 to 35 years), and the final aim was to estimate the inter-correlations of trace elements in normal thyroid of males and their changes with age. All studies were approved by the Ethical Committee of the Medical Radiological Research Center.

\section{Materials and methods}

Samples of the human thyroid were obtained from randomly selected autopsy specimens of 71 males (European-Caucasian) aged 2.0 to 80 years. All the deceased were citizens of Obninsk and had undergone routine autopsy at the Forensic Medicine Department of City Hospital, Obninsk. Age ranges for subjects were divided into two age groups, with group 1, 2.0-35 years (22.5 \pm 1.4 years, $\mathrm{M} \pm \mathrm{SEM}$, $\mathrm{n}=36$ ) and group 2, 36-80 years (52.4 \pm 2.4 years, $\mathrm{M} \pm \mathrm{SEM}, \mathrm{n}=35)$. These groups were selected to reflect the condition of thyroid tissue in the children, teenagers, young adults and first period of adult life (group 1) and in the second period of adult life as well as in old age (group 2). The available clinical data were reviewed for each subject. None of the subjects had a history of an intersex condition, endocrine disorder, or other chronic disease that could affect the normal development of the thyroid. None of the subjects were receiving medications or used any supplements known to affect thyroid trace element contents. The typical causes of sudden death of most of these subjects included trauma or suicide and also acute illness (cardiac insufficiency, stroke, embolism of pulmonary artery, alcohol poisoning). All right lobes of thyroid glands were divided into two portions using a titanium scalpel. ${ }^{34}$ One tissue portion was reviewed by an anatomical pathologist while the other was used for the trace element content determination. A histological examination was used to control the age norm conformity as well as the unavailability of microadenomatosis and latent cancer.

After the samples intended for trace element analysis were weighed, they were transferred to $-20^{\circ} \mathrm{C}$ and stored until the day of transportation in the Medical Radiological Research Center, Obninsk, where all samples were freeze-dried and homogenized. ${ }^{35}$ The pounded sample weighing about $8 \mathrm{mg}$ was applied to the piece of Scotch tape serving as an adhesive fixing backing. ${ }^{36,37}$

To determine the contents of the elements by comparison with a known standard, aliquots of commercial, chemically pure compounds were used. ${ }^{38,39}$ The microliter standards were placed on disks made of thin, ash-free filter papers fixed on the Scotch tape pieces and dried in a vacuum. Ten subsamples of the Certified Reference Material (CRM) IAEA H-4 (animal muscle) weighing about $8 \mathrm{mg}$ were analyzed to estimate the precision and accuracy of results. The CRM IAEA H-4 subsamples were prepared in the same way as the samples of dry homogenized thyroid tissue.

The facility for EDXRF included an annular 109Cd source with an activity of $2.56 \mathrm{GBq}, \mathrm{Si}(\mathrm{Li})$ detector and portable multichannel analyzer combined with a PC. Its resolution was $270 \mathrm{eV}$ at the 5.9 $\mathrm{keV}$ line of $55 \mathrm{Fe}$-source. The duration of the $\mathrm{Br}, \mathrm{Cu}, \mathrm{Fe}, \mathrm{Rb}, \mathrm{Sr}$, and
$\mathrm{Zn}$ measurements was $60 \mathrm{~min}$. The intensity of $\mathrm{K} \alpha$-line of $\mathrm{Br}, \mathrm{Cu}, \mathrm{Fe}$, $\mathrm{Rb}, \mathrm{Sr}$, and $\mathrm{Zn}$ for samples and standards was estimated on calculation basis of the total area of the corresponding photopeak in the spectra. The trace element content was calculated by the relative way of comparing between intensities of $\mathrm{K} \alpha$-lines for samples and standards. Details of the sample preparation, the facility and method of analysis were presented in our previous publication. ${ }^{36,37}$

All thyroid samples were prepared in duplicate, and mean values of trace element contents were used in final calculation. Using Microsoft Office Excel, a summary of the statistics, including, arithmetic mean, standard deviation, standard error of mean, minimum and maximum values, median, percentiles with 0.025 and 0.975 levels was calculated for trace element contents. The reliability of difference in the results between two age groups was evaluated by the parametric Student's t-test and non-parametric Wilcoxon-Mann-Whitney U-test. For the construction of "age - trace element mass fraction" diagrams and the estimation of the Pearson correlation coefficient between different trace elements the Microsoft Office Excel programs were also used.

\section{Results}

Table 1 depicts our data for 6 trace elements in ten sub- samples of CRM IAEA H-4 (animal muscle) and the certified values of this material.

Table I EDXRF data $\mathrm{Br}, \mathrm{Fe}, \mathrm{Rb}, \mathrm{Sr}$, and $\mathrm{Zn}$ contents in the IAEA H-4 (animal muscle) reference material compared to certified values $(\mathrm{mg} / \mathrm{kg}$, dry mass basis)

\begin{tabular}{|c|c|c|c|c|}
\hline \multirow[t]{2}{*}{ Element } & \multicolumn{3}{|c|}{ Certified values } & \multirow{2}{*}{$\begin{array}{l}\text { This work results } \\
\text { Mean士SD }\end{array}$} \\
\hline & Mean & $\begin{array}{l}\text { 95\% Confidence } \\
\text { Interval }\end{array}$ & Type & \\
\hline $\mathrm{Br}$ & 4.1 & $3.5-4.7$ & C & $5.0 \pm 1.2$ \\
\hline $\mathrm{Cu}$ & 4 & $3.6-4.3$ & C & $3.9 \pm 1.1$ \\
\hline $\mathrm{Fe}$ & 49 & $47-51$ & $\mathrm{C}$ & $48 \pm 9$ \\
\hline $\mathrm{Rb}$ & 18 & $17-20$ & C & $22 \pm 4$ \\
\hline $\mathrm{Sr}$ & 0.1 & - & $N$ & $<1$ \\
\hline $\mathrm{Zn}$ & 86 & $83-90$ & C & $90 \pm 5$ \\
\hline
\end{tabular}

Mean, Arithmetical Mean; SD, Standard Deviation; C, Certified Values; N, NonCertified Values.

Table 2 represents certain statistical parameters (arithmetic mean, standard deviation, standard error of mean, minimal and maximal values, median, percentiles with 0.025 and 0.975 levels) of the $\mathrm{Br}, \mathrm{Cu}$, $\mathrm{Fe}, \mathrm{Rb}, \mathrm{Sr}$, and $\mathrm{Zn}$ mass fractions in intact (normal) thyroid of males.

The comparison of our results with published data for the $\mathrm{Br}, \mathrm{Cu}$, $\mathrm{Fe}, \mathrm{Rb}, \mathrm{Sr}$, and $\mathrm{Zn}$ contents in the human thyroid is shown in Table 3.

To estimate the effect of age on the trace element contents we examined two age groups, described above (Table 4). Figure 1 shows the individual data sets for the $\mathrm{Br}, \mathrm{Cu}, \mathrm{Fe}, \mathrm{Rb}, \mathrm{Sr}$, and $\mathrm{Zn}$ mass fraction in all samples of thyroid, and also lines of trend with age. The data of inter-correlation calculations (values of $\mathrm{r}$ - coefficient of correlation) including all trace elements identified by us are presented in Table 5. 

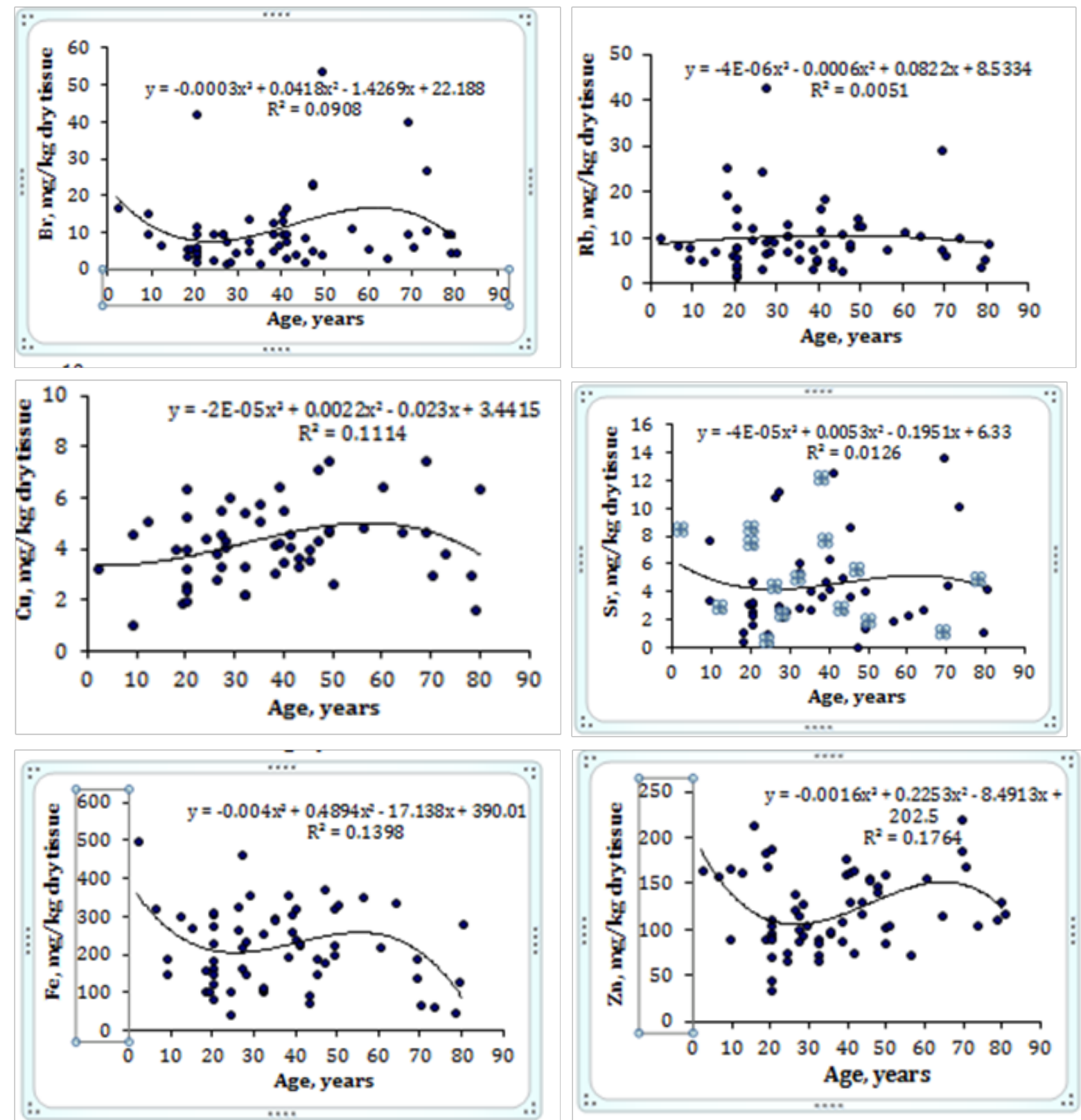

Figure I Data sets of individual $\mathrm{Br}, \mathrm{Cu}, \mathrm{Fe}, \mathrm{Rb}, \mathrm{Sr}$, and $\mathrm{Zn}$ mass fraction values in intact thyroid of males and their trend lines.

Table 2 Some statistical parameters of $\mathrm{Br}, \mathrm{Cu}, \mathrm{Fe}, \mathrm{Rb}, \mathrm{Sr}$, and $\mathrm{Zn}$ mass fraction ( $\mathrm{mg} / \mathrm{kg}$, dry mass basis) in intact thyroid of male

\begin{tabular}{llllllllll}
\hline Gender & Element & Mean & SD & SEM & Min & Max & Median & P 0.025 & P 0.975 \\
\hline Males & $\mathrm{Br}$ & 10.8 & 10 & 1.3 & 1.9 & 54 & 8.05 & 2.33 & 42 \\
$\mathrm{n}=71$ & $\mathrm{Cu}$ & 4.25 & 1.48 & 0.2 & 1.1 & 7.5 & 4.15 & 1.78 & 1.39 \\
& $\mathrm{Fe}$ & 221 & 102 & 13 & 47.1 & 502 & 224 & 58.4 & 419 \\
& $\mathrm{Rb}$ & 10.1 & 6.96 & 0.89 & 1.8 & 43 & 8.6 & 2.65 & 27.5 \\
& $\mathrm{Sr}$ & 4.52 & 3.27 & 0.43 & 0.1 & 14 & 3.55 & 0.443 & 12.4 \\
& $\mathrm{Zn}$ & 122 & 41 & 5.2 & 35.4 & 221 & 115 & 57.2 & 201
\end{tabular}

M, Arithmetic Mean; SD, Standard Deviation; SEM, Standard Error of Mean; Min, Minimum Value; Max, Maximum Value; P 0.025 - percentile with 0.025 level, P 0.975 - percentile with 0.975 level 
Table 3 Median, minimum and maximum value of means $\mathrm{Br}, \mathrm{Cu}, \mathrm{Fe}, \mathrm{Rb}, \mathrm{Sr}$, and $\mathrm{Zn}$ contents in normal thyroid according to data from the literature in comparison with our results $(\mathrm{mg} / \mathrm{kg}$, dry mass basis)

\begin{tabular}{|c|c|c|c|c|}
\hline \multirow[t]{3}{*}{ Element } & \multicolumn{3}{|c|}{ Published data (Reference) } & \multirow{3}{*}{$\begin{array}{l}\text { This work } \\
\text { MISD }\end{array}$} \\
\hline & $\begin{array}{l}\text { Median } \\
\text { of means }\end{array}$ & $\begin{array}{l}\text { Minimum } \\
\text { of means }\end{array}$ & $\begin{array}{l}\text { Maximum } \\
\text { of means }\end{array}$ & \\
\hline & $(\mathbf{n})^{*}$ & $M$ or $M \pm S D,(n)^{* *}$ & $M$ or $M \pm S D,(n) * *$ & \\
\hline $\mathrm{Br}$ & $18.1(11)$ & $5.12(44)^{[25]}$ & $284 \pm 44(14)[26]$ & $10.8 \pm 10.0$ \\
\hline $\mathrm{Cu}$ & $6.1(57)$ & $1.42(120)$ [27] & $220 \pm 22(10)[28]$ & $4.25 \pm 1.48$ \\
\hline $\mathrm{Fe}$ & $252(2 I)$ & $56(120)[27]$ & $2444 \pm 700(14)[26]$ & $221 \pm 102$ \\
\hline $\mathrm{Rb}$ & $12.3(9)$ & $\leq 0.85(29)[29]$ & $294 \pm 191(14)[26]$ & $10.1 \pm 7.0$ \\
\hline $\mathrm{Sr}$ & $0.73(9)$ & $0.55 \pm 0.26(2 \mathrm{I})[30]$ & $46.8 \pm 4.8(4)[28]$ & $4.52 \pm 3.27$ \\
\hline $\mathrm{Zn}$ & II8 (5I) & $32(120)[27]$ & $820 \pm 204(14)[26]$ & $|22 \pm 4|$ \\
\hline
\end{tabular}

M,Arithmetic Mean; SD, Standard Deviation; $(N)^{*}$, Number of All References; $(N)^{* *}$, Number of Samples.

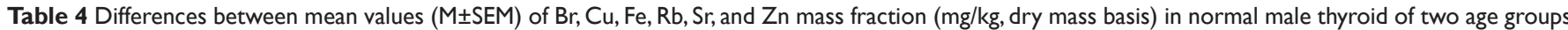
(AG)

\begin{tabular}{|c|c|c|c|c|c|}
\hline Element & \multicolumn{4}{|l|}{ Female thyroid tissue } & $\begin{array}{l}\text { Ratio } \\
\text { AG2 To AG I }\end{array}$ \\
\hline $\mathrm{Cu}$ & $3.93 \pm 0.27$ & $4.58 \pm 0.28$ & 0.098 & $>0.05$ & 1.17 \\
\hline $\mathrm{Rb}$ & $10.4 \pm 1.4$ & $9.65 \pm 1.09$ & 0.682 & $>0.05$ & 0.93 \\
\hline $\mathrm{Sr}$ & $4 .|5 \pm 0.5|$ & $4.94 \pm 0.71$ & 0.273 & $>0.05$ & 1.19 \\
\hline $\mathrm{Zn}$ & $112 \pm 7$ & $135 \pm 7$ & 0.024 & $\leq .1$ & 1.21 \\
\hline
\end{tabular}

M,Arithmetic Mean; SEM, Standard Error of Mean;T-Test, Student's T-Test U-Test Wilcoxon-Mann Whitney U-Test Sstatistically Significant Values Are in Bold

Table 5 Intercorrelations of the chemical element mass fractions in the intact thyroid of male of three age groups ( $r$ - coefficient of correlation)

\begin{tabular}{|c|c|c|c|c|c|c|}
\hline Element & $\mathbf{B r}$ & $\mathrm{Cu}$ & $\mathbf{F e}$ & $\mathbf{R b}$ & Sr & Zn \\
\hline \multicolumn{7}{|c|}{ 2-35 years } \\
\hline $\mathrm{Br}$ & I & -0.206 & 0.059 & 0.148 & $0.380 \mathrm{a}$ & $0.518 b$ \\
\hline $\mathrm{Cu}$ & -0.206 & I & $0.420 \mathrm{a}$ & $0.364 a$ & $-0.349 a$ & -0.102 \\
\hline $\mathrm{Fe}$ & 0.059 & $0.420 \mathrm{a}$ & I & 0.254 & $0.312 \mathrm{a}$ & $0.29 \mathrm{Ia}$ \\
\hline $\mathrm{Rb}$ & 0.148 & $0.364 a$ & 0.254 & I & -0.028 & 0.067 \\
\hline $\mathrm{Sr}$ & $0.380 \mathrm{a}$ & $-0.349 a$ & $0.312 \mathrm{a}$ & -0.028 & I & $0.335 a$ \\
\hline $\mathrm{Zn}$ & $0.518 b$ & -0.102 & $0.291 \mathrm{a}$ & 0.067 & $0.335 \mathrm{a}$ & I \\
\hline \multicolumn{7}{|c|}{$36-80$ years } \\
\hline $\mathrm{Br}$ & I & $0.398 a$ & $0.24 I$ & $0.563 \mathrm{~b}$ & 0.234 & 0.297 \\
\hline $\mathrm{Cu}$ & $0.398 a$ & 1 & $0.442 \mathrm{a}$ & 0.187 & -0.058 & $0.399 \mathrm{a}$ \\
\hline $\mathrm{Fe}$ & $0.24 I$ & $0.442 \mathrm{a}$ & I & 0.09 & -0.166 & -0.103 \\
\hline $\mathrm{Rb}$ & $0.563 b$ & 0.187 & 0.09 & I & $0.36 \mathrm{Ia}$ & 0.233 \\
\hline $\mathrm{Sr}$ & 0.234 & -0.058 & -0.166 & $0.36 \mathrm{la}$ & 1 & -0.042 \\
\hline $\mathrm{Zn}$ & 0.297 & $0.399 a$ & -0.103 & 0.233 & -0.042 & 1 \\
\hline
\end{tabular}


Table Continued...

\begin{tabular}{lllllll}
\hline Element & $\mathbf{B r}$ & $\mathbf{C u}$ & $\mathbf{F e}$ & $\mathbf{R b}$ & $\mathbf{S r}$ & $\mathbf{Z n}$ \\
\hline $\mathbf{2 - 8 0}$ years & & & & & & \\
$\mathrm{Br}$ & $\mathrm{I}$ & $0.285 \mathrm{a}$ & 0.15 & $0.299 \mathrm{a}$ & $0.302 \mathrm{a}$ & $0.408 \mathrm{~b}$ \\
$\mathrm{Cu}$ & $0.285 \mathrm{a}$ & $\mathrm{I}$ & $0.413 \mathrm{~b}$ & $0.273 \mathrm{a}$ & -0.147 & 0.218 \\
$\mathrm{Fe}$ & 0.15 & $0.413 \mathrm{~b}$ & $\mathrm{I}$ & 0.197 & 0.072 & 0.133 \\
$\mathrm{Rb}$ & $0.299 \mathrm{a}$ & $0.273 \mathrm{a}$ & 0.197 & $\mathrm{I}$ & 0.112 & 0.098 \\
$\mathrm{Sr}$ & $0.302 \mathrm{a}$ & -0.147 & 0.072 & 0.112 & $\mathrm{I}$ & 0.174 \\
$\mathrm{Zn}$ & $0.408 \mathrm{~b}$ & 0.218 & 0.133 & 0.098 & 0.174 & $\mathrm{I}$ \\
\hline
\end{tabular}

Sstatistically significant values, ${ }^{a} p \leq 0.05,{ }^{b} p \leq 0.0$ I

\section{Discussion}

A set of existing international CRM prepared from the soft tissues of humans and animals is extremely limited. As is was previously discussed [36] 97\% of the self-absorption in the dry sample of human tissue is due to the content of bulk elements: carbon (C), nitrogen $(\mathrm{N})$, oxygen $(\mathrm{O})$, phosphorus $(\mathrm{P})$, and sulfur $(\mathrm{S})$, as well as main electrolytes: calcium $(\mathrm{Ca})$, chlorine $(\mathrm{Cl})$, and sodium $(\mathrm{Na})$. The content of these elements and the mass density of muscle and thyroid in humans are virtually identical. ${ }^{37}$ Accordingly, the use of CRM IAEA H-4 as a CRM for the analysis of samples of thyroid tissue can be seen as quite acceptable. Good agreement of the $\mathrm{Br}, \mathrm{Cu}, \mathrm{Fe}, \mathrm{Rb}, \mathrm{Sr}$, and $\mathrm{Zn}$ contents analyzed by EDXRF with the certified data of CRM IAEA H-4 (Table 1) indicates an acceptable accuracy of the results obtained in the study of trace elements of the thyroid presented in Tables 2-5.

The obtained means for $\mathrm{Br}, \mathrm{Cu}, \mathrm{Fe}, \mathrm{Rb}, \mathrm{Sr}$, and $\mathrm{Zn}$ mass fraction, as shown in Table 3, agree well with the medians of mean values cited by other researches for the human thyroid, including samples received from persons who died from different non-thyroid diseases. ${ }^{24-30}$ A number of values for chemical element mass fractions were not expressed on a dry mass basis by the authors of the cited references. However, we calculated these values using published data for water $(75 \%)^{40}$ and ash $(4.16 \% \text { on dry mass basis })^{41}$ contents in thyroid of adults.

A strongly pronounced tendency of age-related increase in $\mathrm{Zn}$ mass fraction was observed in thyroid of males (Table 4). In second group of males the mean $\mathrm{Zn}$ mass fraction in thyroids was 1.21 times higher than in thyroids of the first age group. There were no statistically significant differences between the $\mathrm{Br}, \mathrm{Cu}, \mathrm{Fe}, \mathrm{Rb}$, and $\mathrm{Sr}$ mass fractions within different age-groups. No published data referring to age-related changes of $\mathrm{Br}, \mathrm{Cu}, \mathrm{Fe}, \mathrm{Rb}, \mathrm{Sr}$, and $\mathrm{Zn}$ mass fractions in human thyroid was found.

A significant direct correlation between the $\mathrm{Zn}$ and $\mathrm{Br}, \mathrm{Zn}$ and $\mathrm{Fe}, \mathrm{Zn}$ and $\mathrm{Sr}, \mathrm{Br}$ and $\mathrm{Sr}, \mathrm{Cu}$ and $\mathrm{Fe}, \mathrm{Cu}$ and $\mathrm{Ru}, \mathrm{Fe}$ and $\mathrm{Sr}$ mass fractions as well as an inverse correlation between $\mathrm{Cu}$ and $\mathrm{Sr}$ mass fractions was seen in male thyroid of the first age group (Table 5). In age group 2 many correlations between trace elements in thyroid found in the age group 1 are no longer evident (Table 5). For example, all correlations between $\mathrm{Zn}$ and other trace elements existed in the age from 2 to 35 years disappeared but new correlation $\mathrm{Zn}-\mathrm{Cu}$ was arisen. Thus, if we accept the levels and relationships of trace element mass fraction in thyroid glands of males in the age range 2 to 35 years as a norm, we have to conclude that after age 35 years the level of $\mathrm{Zn}$ and relationships of trace elements in thyroid significantly changed. If some positive correlations between the elements in the group 1 were predictable (e.g., $\mathrm{Fe}-\mathrm{Cu}$ ), the interpretation of other observed relationships and their disturbance with age requires further study for a more complete understanding. No published data referring to intercorrelations of $\mathrm{Br}, \mathrm{Cu}, \mathrm{Fe}, \mathrm{Rb}, \mathrm{Sr}$, and $\mathrm{Zn}$ mass fractions in human thyroid and age-related changes of these inter-correlations was found.

An age-related increase and excess in metal mass fractions in thyroid tissue, including $\mathrm{Zn}$, may contribute to harmful effects on the gland. There are good reasons for such speculations since many reviews and numerous papers raise the concern about toxicity and tumorigenesis of the metals. ${ }^{42-76}$ Excessive thyroid $\mathrm{Zn}$ level in the older males may be harmful to normal metabolism of cells. ${ }^{77}$ For example, $\mathrm{Zn}$ enhances the activity of telomerase, ${ }^{78}$ an enzyme thought to be responsible for unlimited cell proliferation. ${ }^{79}$ Excessive $\mathrm{Zn}$ intake has undesirable metabolic effects, such as immune dysfunction $^{80}$ and impaired antioxidant defense. ${ }^{81}$ By now much data has been obtained related both to the direct and indirect action of $\mathrm{Zn}$ on the DNA polymeric organisation, replication and lesions, and to its vital role for cell division. ${ }^{82,83}$ Moreover, it is known that $\mathrm{Zn}$ is an inhibitor of the $\mathrm{Ca}$-dependent apoptotic endonuclease, which takes part in the internucleosomal fragmentation of DNA. Its consequence is a depression of cell apoptosis. ${ }^{84}$ Some other ways for $\mathrm{Zn}$ to act as a potent anti-apoptotic agent have also been described ${ }^{85-88}$ All these facts imply that age-related excessive $\mathrm{Zn}$ concentrations in thyroid tissue are probably one of the factors influencing goiter, benign, and malignant tumor of the male thyroid.

All the deceased were citizens of Obninsk. Obninsk is the small nonindustrial city not far from Moscow in unpolluted area. None of those who died a sudden death had suffered from any systematic or chronic disorders before. The normal state of thyroid was confirmed by morphological study. Thus, our data for $\mathrm{Br}, \mathrm{Cu}, \mathrm{Fe}, \mathrm{Rb}, \mathrm{Sr}$, and $\mathrm{Zn}$ mass fractions in intact thyroid may serve as indicative normal values for males of urban population of the Russian Central European region.

This study has several limitations. Firstly, it would be interesting in future studies to examine the $\mathrm{Zn}$ and other trace element levels using similar technique in autopsy specimens of females. Future studies should be also directed toward using other analytical methods which allow extend the list of chemical elements investigated in thyroid tissue.

\section{Conclusion}

The 109Cd radionuclide-induced energy-dispersive X-ray fluorescence analysis is a useful analytical tool for the non-destructive determination of trace element content in the thyroid tissue samples. This method allows determine means for $\mathrm{Br}, \mathrm{Cu}, \mathrm{Fe}, \mathrm{Rb}, \mathrm{Sr}$, and $\mathrm{Zn}$ (6 trace elements). Our data reveal that there is strongly pronounced tendency of increase in $\mathrm{Zn}$ mass fraction in the normal thyroid of male 
during a lifespan. Therefore, a goitrogenic and tumorogenic effect of excessive $\mathrm{Zn}$ level in the thyroid of old males and of disturbance in intrathyroidal trace element relationships with increasing age may be assumed.

\section{Acknowledgments}

We are grateful to Dr. Yu. Choporov, Head of the Forensic Medicine Department of City Hospital, Obninsk, for supplying thyroid samples.

\section{Conflict of interest}

There is no conflict of interest in composing this manuscript.

\section{References}

1. Gesing A. The thyroid gland and the process of aging. Thyroid Research $2015 ; 8(1): 8$.

2. Mitrou P, Raptis SA, Dimitriadis G . Thyroid disease in older people Maturitas. 2011;70(1):5-9.

3. Kwong N, Medici M, Angell TE, et al. The influence of patient age on thyroid nodule formation, multinodularity, and thyroid cancer risk. J Clin Endocrinol Metab. 2015;100(12):434-440.

4. Mazzaferri E. Management of a solitary thyroid nodule. $N$ Engl J Med. 1993;328(8):553-559.

5. Smailyte G, Kaubriene ME, Kurtinaitis J. Increasing thyroid cancer incidence in Lithuania in 1978-2003. BMC Cancer. 2006;11(6):284.

6. Olinski R, Siomek A, Rozalski R, et al. Oxidative damage to DNA and antioxidant status in aging and age-related diseases. Acta Biochim Pol. 2007;54(1):11-26.

7. Minelli A, Bellezza I, Conte C, et al. Oxidative stress-related aging: A role for prostate cancer? Biochim Biophys Acta. 2009;1795(2):83-91.

8. Klaunig JE, Kamendulis LM, Hocevar BA. Oxidative stress and oxidative damage in carcinogenesis. Toxicol Pathol. 2010;38(1):96-109.

9. Järup L. Hazards of heavy metal contamination. $\mathrm{Br}$ Med Bull. 2003;68:167-182.

10. Zaichick V, Zaichick S. Role of zinc in prostate cancerogenesis. In: Mengen, Spurenelemente, 19 Arbeitstagung Jena. 1999;104-115.

11. Zaichick V. INAA and EDXRF applications in the age dynamics assessment of $\mathrm{Zn}$ content and distribution in the normal human prostate. J Radioanal Nucl Chem. 2004;262(1):229-234.

12. Zaichick V. Medical elementology as a new scientific discipline. $J$ Radioanal Nucl Chem. 2006;269(2):303-309.

13. Toyokuni S. Molecular mechanisms of oxidative stress-induced carcinogenesis: from epidemiology to oxygenomics. IUBMB Life. 2008;60(7):441-447.

14. Gupte A, Mumper RJ. Elevated copper and oxidative stress in cancer cells as a target for cancer treatment. Cancer Treat Rev. 2009;35(1):32-46.

15. Lee JD, Wu SM, Lu LY, et al. Cadmium concentration and metallothionein expression in prostate cancer and benign prostatic hyperplasia of humans. J Formos Med Assoc. 2009;108(7):554-559.

16. Zaichick V, Tsyb A, Vtyurin BM. Trace elements and thyroid cancer Analyst. 1995;120(3):817-821.

17. Zaichick V, Choporov Yu. Determination of the natural level of human intra-thyroid iodine by instrumental neutron activation analysis. $J$ Radioanal Nucl Chem. 1996;207(1):153-161.

18. Zaichick V, Zaichick S. Normal human intrathyroidal iodine. Sci Total Environ. 1997;206(1):39-56.
19. Zaichick V. Iodine excess and thyroid cancer. $J$ Trace Elements in Experimental Medicine. 1998;11(4):508-509.

20. Zaichick V. In vivo and in vitro application of energy-dispersive XRF in clinical investigations: experience and the future. $J$ Trace Elements in Experimental Medidicne. 1998;11(4):509-510.

21. Zaichick V, Iljina T. Dietary iodine supplementation effect on the rat thyroid 131I blastomogenic action. In: Die Bedentung der Mengen- und Spurenelemente. 18 Arbeitstangung Jena. 1998;294-306.

22. Zaichick V, Zaichick S. Energy-dispersive X-ray fluorescence of iodine in thyroid puncture biopsy specimens. J Trace and Microprobe Techniques. 1999;17(2):219-232.

23. Zaichick V. Human intrathyroidal iodine in health and non-thyroidal disease. New aspects of trace element research. In: Abdulla M, editor. Smith-Gordon and Nishimura, London and Tokyo; 1999;114-119.

24. Zaichick V. Relevance of and potentiality for in vivo intrathyroidal iodine determination. In: In Vivo Body Composition Studies. Yasumura S, editor. Academy of Sciences, Annals of the New York, USA; 2000.

25. Zhu H, Wang N, Zhang Y, et al. Element contents in organs and tissues of Chinese adult men. Health Phys. 2010;98(1):61-73.

26. Salimi J, Moosavi K, Vatankhah S, et al. Investigation of heavy trace elements in neoplastic and non-neoplastic human thyroid tissue: A study by proton - induced X-ray emissions. Iran $J$ Radiat Res. 2004;1(4):211-216.

27. Ataulchanov IA. Age-related changes of manganese, cobalt, coper, zinc, and iron contents in the endocrine glands of females. Problemy Endocrinologii. 1969;15(2):98-102.

28. Reddy SB, Charles MJ, Kumar MR, et al. Trace elemental analysis of adenoma and carcinoma thyroid by PIXE method. Nucl Instr Meth Phys Res. 2002;196(3-4):333-339.

29. Boulyga SF, Zhuk IV, Lomonosova EM, et al. Determination of microelements in thyroids of the inhabitants of Belarus by neutron activation analysis using the k0-method. $J$ Radioanal Nucl Chem. 1997;222(1-2):11-14.

30. Tipton IH, Cook MJ. Trace elements in human tissue. Part II. Adult subjects from the United States. Health Phys. 1963;9(2):103-145.

31. Zaichick V. Sampling, sample storage and preparation of biomaterials for INAA in clinical medicine, occupational and environmental health. In: Harmonization of Health-Related Environmental Measurements Using Nuclear and Isotopic Techniques. IAEA Vienna. 1997;123-133.

32. Zaichick V. Losses of chemical elements in biological samples under the dry ashing process. Trace Elements in Medicine. 2004;5(3):17-22.

33. Zaichick V, Zaichick S. INAA applied to halogen (Br and I) stability in long-term storage of lyophilized biological materials. J Radioanal Nucl Chem. 2000;244(2):279-281.

34. Zaichick V, Zaichick S. Instrumental effect on the contamination of biomedical samples in the course of sampling. The Journal of Analytical Chemistry. 1996;51(12):1200-1205.

35. Zaichick V, Zaichick S. A search for losses of chemical elements during freeze-drying of biological materials. $J$ Radioanal Nucl Chem. 1997;218(2):249-253.

36. Zaichick S, Zaichick V. Method and portable facility for energydispersive X-ray fluorescent analysis of zinc content in needle-biopsy specimens of prostate. X-Ray Spectrom. 2010;39(2):83-89.

37. Zaichick $\mathrm{S}$, Zaichick $\mathrm{V}$. The $\mathrm{Br}, \mathrm{Fe}, \mathrm{Rb}, \mathrm{Sr}$, and $\mathrm{Zn}$ content and interrelation in intact and morphologic normal prostate tissue of adult men investigated by energy dispersive X-ray fluorescent analysis. X-Ray Spectrom. 2011;40(6):464-469. 
38. Zaichick V. Applications of synthetic reference materials in the medical Radiological Research Centre. Fresenius J Anal Chem. 1995;352(1-2):219-223.

39. International Commission on Radiological Protection (ICRP). Report of the Task Group on reference Man (Report No 23) Pergamon Press, Oxford, UK; 1975.

40. Katoh Y, Sato T, Yamamoto Y. Determination of multielement concentrations in normal human organs from the Japanese. Biol Trace Elem Res. 2002;90(1-3):57-70.

41. Schroeder HA, Tipton IH, Nason AP. Trace metals in man: strontium and barium. J Chron Dis. 1972;25(9):491-517.

42. Sunderman FW. Mechanism of metal carcinogenesis. Biol Trace Elem Res. 1979;1(1):63-86.

43. Snow ET. Metal carcinogenesis: mechanistic implications. Pharmacol Ther. 1992;53:31-65.

44. Toyokuni S. Role of iron in carcinogenesis: cancer as a ferrotoxic disease. Cancer Sci. 2009;100(1):9-16.

45. Zamudio MR, Ha HC. Environmental epigenetics in metal exposure. Epigenetics. 2011;6(7):820-827.

46. Tokar EJ, Tallaa BL,Waalkes MP. Metal ions in human cancer development. Met Ions Life Sci. 2011;8:375-401.

47. Tchounwou PB, Yedjou CG, Patlolla AK, et al. Heavy metal toxicity and the environment. Molecular, Clinical and Environmental Toxicology. 2012;101:133-164.

48. Koedrith P, Kim H, Weon JI, et al. Toxicogenomic approaches for understanding molecular mechanisms of heavy metal mutagenicity and carcinogenicity. Int J Hyg Environ Health. 2013;216(5):587-598.

49. Tabrez S, Priyadarshini M, Priyamvada S, et al. Gene-environment interactions in heavy metal and pesticide carcinogenesis. Mutat Res Genet Toxicol Environ Mutagen. 2014;760:1-9.

50. Zaichick V, Zaichick S. Role of zinc in prostate cancerogenesis. In Mengen und Spurenelemente. 19. Arbeitstagung, Anke M, editors. Friedrich-Schiller-Universitat, Jena, Germany; 1999. p. 104-115.

51. Zaichick V. INAA and EDXRF applications in the age dynamics assessment of $\mathrm{Zn}$ content and distribution in the normal human prostate. J Radioanal Nucl Chem. 2004;262(1):229-234.

52. Zaichick S, Zaichick V. INAA application in the age dynamics assessment of $\mathrm{Br}, \mathrm{Ca}, \mathrm{Cl}, \mathrm{K}, \mathrm{Mg}, \mathrm{Mn}$, and $\mathrm{Na}$ content in the normal human prostate. $J$ Radioanal Nucl Chem. 2011;288(1):197-202.

53. Zaichick S, Zaichick V. The effect of age on Ag, Co, Cr, Fe, Hg, Sb, $\mathrm{Sc}, \mathrm{Se}$, and $\mathrm{Zn}$ contents in intact human prostate investigated by neutron activation analysis. Appl Radiat Isot. 2011;69(9):827-833.

54. Zaichick V, Nosenko S, Moskvina I. The effect of age on 12 chemica element contents in intact prostate of adult men investigated by inductively coupled plasma atomic emission spectrometry. Biol Trace Elem Res. 2012;147(1):49-58.

55. Zaichick S, Zaichick V, Nosenko S, et al. Mass Fractions of 52 Trace Elements and Zinc Trace Element Content Ratios in Intact Human Prostates Investigated by Inductively Coupled Plasma Mass Spectrometry. Biol Trace Elem Res. 2012;149(2):171-183.

56. Zaichick V, Zaichick S. INAA application in the assessment of chemical element mass fractions in adult and geriatric prostate glands. Appl Radiat Isot. 2014;90:62-73.

57. Zaichick V, Zaichick S. Determination of trace elements in adults and geriatric prostate combining neutron activation with inductively coupled plasma atomic emission spectrometry. Open Journal of Biochemistry. 2014;1(2):16-33.
58. Zaichick V, Zaichick S. Use of INAA and ICP-MS for the assessment of trace element mass fractions in adult and geriatric prostate. J Radioanal Nucl Chem. 2014;301(2):383-397.

59. Zaichick V, Zaichick S. Age-related histological and zinc content changes in adult nonhyperplastic prostate glands. Age 2014;36(1):167-181.

60. Zaichick V, Zaichick S. Differences and relationships between morphometric parameters and zinc content in nonhyperplastic and hyperplastic prostate glands. BJMMR. 2015;8(8):692-706.

61. Zaichick V, Zaichick S, Davydov G. Differences between chemical element contents in hyperplastic and nonhyperplastic prostate glands investigated by neutron activation analysis. Biol Trace Elem Res. 2015;164:25-35.

62. Zaichick S, Zaichick V. Prostatic Tissue Level of some Androgen Dependent and Independent Trace Elements in Patients with Benign Prostatic Hyperplasia. Androl Gynecol Curr Res. 2015;3:3.

63. Zaichick V, Zaichick S. The Bromine, Calcium, Potassium, Magnesium, Manganese, and Sodium Contents in Adenocarcinoma of Human Prostate Gland. J Hematology and Oncology Research. 2016;2(2):1-12.

64. Zaichick V, Zaichick S. Trace element contents in adenocarcinoma of human prostate investigated by energy dispersive X-ray fluorescent analysis. Journal of Adenocarcinoma. 2016;1(1):1-7.

65. Zaichick V, Zaichick S. Trace element contents in adenocarcinoma of the human prostate gland investigated by neutron activation analysis. Cancer Research and Oncology. 2016;1(1):1-10.

66. Zaichick V, Zaichick S. Variations in concentration and distribution of several androgen-dependent and-independent trace elements in nonhyperplastic prostate gland tissue throughout adulthood. $J$ Androl Gynaecol. 2016;4(1):1-10.

67. Zaichick V, Zaichick S. Prostatic tissue levels of 43 trace elements in patients with prostate adenocarcinoma. Cancer \& Clinical Oncology. 2016;5(1):79-94.

68. Zaichick V, Zaichick S.Levels of 43 trace elements in hyperplastic prostate tissues. British J Medicine \& Medical Research. 2016;15(2):1-12.

69. Zaichick V, Zaichick S. Prostatic tissue level of some major and trace elements in patients with BPH. JJ Nephro Urol. 2016;3(1):25.

70. Zaichick V, Zaichick S. Age-related changes in concentration and histological distribution of $\mathrm{Br}, \mathrm{Ca}, \mathrm{Cl}, \mathrm{K}, \mathrm{Mg}, \mathrm{Mn}$, and $\mathrm{Na}$ in nonhyperplastic prostate of adults. European $J$ Biology \& Medical Science Research. 2016;4(2):31-48.

71. Zaichick V, Zaichick S. Variations in concentration and histologica distribution of $\mathrm{Ag}, \mathrm{Co}, \mathrm{Cr}, \mathrm{Fe}, \mathrm{Hg}, \mathrm{Rb}, \mathrm{Sb}, \mathrm{Sc}, \mathrm{Se}$, and $\mathrm{Zn}$ in nonhyperplastic prostate gland throughout adulthood. Jacobs J Cell \& Molecular Biology. 2016;2(1):11.

72. Zaichick V, Zaichick S. Age-related Changes in Concentration and Histological Distribution of 18 Chemical Elements in Nonhyperplastic Prostate of Adults. World Journal of Pharmaceutical and Medical Research. 2016;2(4):5-18.

73. Zaichick V, Zaichick S. Age-related changes in concentration and histological distribution of 54 trace elements in non hyper plastic prostate of adults. Int Arch Urol Complic. 2016;2(2):19.

74. Zaichick V, Zaichick S. The Comparison between the contents and interrelationships of 17 chemical elements in normal and cancerous prostate gland. J Prostate Cancer. 2016;1(1):105.

75. Zaichick V, Zaichick S, Wynchank S. Intracellular zinc excess as one of the main factors in the etiology of prostate cancer. J Analytical Oncology. 2016;5(3):124-131.

76. Zaichick V, Zaichick S, Rossmann M. Intracellular calcium excess as one of the main factors in the etiology of prostate cancer. AIMS Molecular Science. 2016;3(4):635-647. 
77. Bozym RA, Chimienti F, Giblin LJ, et al. Free zinc ions outside a narrow concentration range are toxic to a variety of cells in vitro. Exp Biol Med (Maywood). 2010;235(6):741-750.

78. Nemoto K, Kondo Y, Himeno S, et al. Modulation of telomerase activity by zinc in human prostatic and renal cancer cells. Biochem Pharmacol. 2000;59:401-405

79. Sommerfeld HJ, Meeker AK, Piatyszek MA, et al. Telomerase activity: a prevalent marker of malignant human prostate tissue. Cancer Res. $1996 ; 56: 218-226$.

80. Chandra RK. Excessive intake of zinc impairs immune responses. JAMA. 1984;252(11):1443-1446.

81. Samman S, Roberts DC. The effect of zinc supplements on lipoproteins and copper status. Atherosclerosis. 1988;70(3):247-252.

82. Schwartz MK. Role of trace elements in cancer. Cancer Res. 1975;35(11):3481-3487.

83. Blok LJ, Grossmann ME, Perry JE, et al. Characterization of an early growth response gene, which encodes a zinc finger transcription factor, potentially involved in cell cycle regulation. Mol Endocrinol. 1995;9(11):1610-1620.
84. Zezerov YeG. Hormonal and molecular-biological factors of prostate cancer pathogenesis. Voprosy Oncologii. 2000;47(2):174-181.

85. Truong-Tran AQ, Ho LH, Chai F, et al. Cellular zinc fluxes and the regulation of apoptosis/gene-directed cell death. J Nutr. 2000;130(5S Suppl):1459S-1466S.

86. Kontargiris E, Vadalouka A, Ragos V, et al. Zinc inhibits apoptosis and maintains NEP downregulation, induced by Ropivacaine, in HaCaT cells. Biol Trace Elem Res. 2012;150:460-466.

87. Liang D, Yang M, Guo B, et al. Zinc inhibits H2O2-induced MC3T3-E1 cells apoptosis via MAPK and PI3K/AKT pathways. Biol Trace Elem Res. 2012;148(3):420-429.

88. Zhang X, Liang D, Guo B, et al. Zinc inhibits high glucose-induced apoptosis in peritoneal mesothelial cells. Biol Trace Elem Res. 2012;150:424-432. 